\title{
La construcción mítica del Quinto Imperio portugués entre sus orígenes y la crisis de la modernidad
}

\author{
José Luis GómEZ VÁZQUEZ \\ Universidad Nacional Autónoma de México
}

Los mitos sobre el destino de la nación portuguesa han sido interpretados constantemente a lo largo de su tradición literaria y se han adecuado a las circunstancias políticas y las necesidades discursivas de cada periodo. Géneros como la historiografía, la epopeya, el sermón y la lírica han sabido aprovechar el repertorio mítico para crear textos determinantes en la construcción de la identidad nacional portuguesa. Las bases del mito utópico del Quinto Imperio se pueden rastrear desde la más temprana literatura portuguesa y derivar en las más complejas reelaboraciones de la literatura moderna del país. Este ensayo repasa los textos de mayor importancia en la evolución y resignificación de este mito en función de sus contextos histórico-literarios.

PALABRAS ClaVE: Portugal, identidad nacional, sebastianismo, Quinto Imperio, tradición literaria.

Myths about the fate of the Portuguese nation have had different interpretations throughout their literary tradition and often were adapted to the political circumstances and the discursive needs in each period. Genres such as historiography, epic, sermon and poetry had taken advantage of this mythical repertoire to create texts that were decisive in the construction of Portuguese national identity. The bases of the Fifth Empire's utopian myth can be traced from the earliest Portuguese literature and derive in the most complex reprocessings of Portuguese modern literature. This paper reviews the most important texts within the evolution and resignification of this myth depending on its historical-literary contexts.

KEY WORDS: Portugal, national identity, sebastianismo, Fifth Empire, tradition.

\section{De la génesis del mito de Portugal a la profecía del destino imperial}

Es un hecho aceptado que el conjunto de experiencias pasadas en común constituye uno de los principales vínculos de identidad de una nación. La escritura historiográfica y la literatura contribuyen en buena medida a la consolidación de tales vínculos por medio de la elaboración de repertorios de relatos propios de la comunidad, lo cual se puede constatar en cualquier grupo que se reconozca o busque reconocerse como nación e intente diferenciarse de otros. Particulares son, sin embargo, los relatos que proyectan la identidad desde el pasado hacia el futuro y funden la documentación de 
los hechos con la visión de un destino, el rigor pericial del historiador con la gravedad misteriosa del profeta. Las circunstancias en que estos relatos se producen y reciben llegan a ser tan complejas que penetran las altas esferas políticas y terminan por convertirse a su vez en acontecimientos históricos dignos de memoria. Es el caso del llamado Quinto Imperio, utopía judaico-portuguesa a la que el afamado teólogo Vieira habría de dar forma en varios de sus sermones, pero particularmente en su História do futuro.

Conocido por su obra teológica y por sus gestiones para la Compañía General de Comercio de Brasil, el Padre Vieira apenas dio forma definitiva a un complejo de relatos y visiones que venían preparando a Portugal para un momento clave en la historia de su identidad como nación: la recuperación de su independencia, perdida décadas antes con la muerte del rey Don Sebastián en la batalla de Alcazarquivir, que daría pie a uno de los mitos de mayor repercusión en la literatura, el arte e incluso de la "mentalidad" — si es que cabe aplicar un término como éste a todo un pueblo_ portugueses.

La idea del Quinto Imperio proviene de un pasaje del segundo capítulo del libro de Daniel, el cual se presta a varias interpretaciones en la tradición textual rabínica. Con una despierta sensibilidad ante la crisis económica y política de Portugal y dotado de una admirable habilidad oratoria, el Padre Vieira supo hacer de un oscuro pasaje bíblico la síntesis de un mito al cual daría una orientación teleológica como un conjunto de acciones necesarias para salvar, según su perspectiva, al reino de Portugal.

Durante la "dominación filipina" (el gobierno de Portugal a manos de los monarcas españoles Felipe II y Felipe III), las políticas españolas de "limpieza de sangre", promovidas por la Santa Inquisición a la que estos monarcas habían empoderado, condujeron a la expulsión de judíos y musulmanes del territorio portugués; las consecuencias económicas de tal acontecimiento no tardaron en hacerse notar en ambos reinos, obnubilados quizá por las ganancias provenientes de sus colonias. En el caso particular de Portugal, muchas de las familias judías emigraron, con todo y sus capitales, a Holanda, favoreciendo el desarrollo comercial de esta región. El plan de Vieira consistía en que, una vez recuperada la independencia de Portugal a partir de 1640, las políticas de "limpieza de sangre" se "suavizaran" con los judíos emigrados, de modo que se les permitiera volver, obteniendo a cambio los capitales y recursos necesarios para la recuperación económica del reino, gravemente afectado por las políticas económicas de ambos Felipes (Saraiva, 1992: 75).

Como hombre de Iglesia con una aguda visión de Estado, y bajo la mirada suspicaz de la Corona, pero sobre todo de la Inquisición — que lo procesó en 1665 sin grandes consecuencias, debido a su prestigio como orador y al apoyo de los jesuitas-, el padre Vieira comenzaría a trabajar en su História do futuro, un texto que intenta trazar, como su título lo indica, una visión teológicamente soportada del futuro del reino, en el que, como era de esperar, habían de estar incluidos los judíos holandeses repatriados. A la luz de esta necesidad política se puede entender que un texto "teológico" plantee, si no una utopía en el sentido más estricto del término, al menos sí un topos proyectado a 
futuro, donde de la convivencia o incluso de la fusión de dos credos milenarios naciera un Quinto Imperio, el último y definitivo.

La Historia se encargaría de documentar las repercusiones del libro de Vieira en las políticas de la Corona portuguesa; sin embargo, para la literatura es de especial interés observar en qué condiciones pudo haberse leído y con qué expectativas, así como la manera en que convivió con textos contemporáneos conocidos por el autor y aprovechados para orientar mejor la significación del propio.

\subsection{Leyenda, oralidad y profecía de un reino definitivo}

Uno de los componentes más antiguos de la mitología de identidad portuguesa se remonta a la batalla en los campos de Ourique en el siglo XII, donde el conde D. Afonso Henriques obtuvo una importante victoria en la guerra de Reconquista contra los entonces llamados moros. El condado de Portugal dependía del reino de León y fue a partir de esta victoria que D. Afonso Henriques se pudo proclamar rey de Portugal y declarar la independencia del reino, que pronto fue reconocida. A los hechos históricos debe agregarse uno legendario: la víspera de la batalla, un rayo luminoso trajo a D. Afonso la visión de Cristo crucificado, quien le prometió la victoria en ésa y otras batallas, que representarían las primeras piedras de un imperio. Las cinco monedas de una de las antiguas banderas de Portugal (que hoy aparecen como cinco pequeños escudos en forma de cruz) representan las llagas de Cristo en alusión a ese milagro fundacional. Los hechos de Ourique representan el primer estrato o componente de un mito de nacionalidad que la tradición literaria en Portugal habría de sustentar mientras la ilusión del dominio ultramarino perviviera. Según algunas versiones del mito, las palabras del Cristo de Ourique designaban al imperio portugués como el imperio de Dios.

Estos hechos fundacionales trascenderán tanto en el discurso histórico —en las crónicas de los reinos ${ }^{1}$ - como en el literario - en Os Lusíadas, ${ }^{2}$ la epopeya nacional portuguesa, de cuya importancia se hablará más adelante.

Pero entre los hechos de Ourique, las crónicas del reino y la epopeya de Camões, otros textos y hechos históricos contribuirían a conformar el destino mesiánico de Portugal. El filósofo António Quadros resalta la importancia de un conjunto de textos que, hacia la tercera década del siglo XVI, circulaban entre la oralidad y los manuscritos bajo el nombre de Trovas de Bandarra (1982: 25-36).

Poeta popular, Gonçalo Anes Bandarra pregonaba la unificación política y religiosa del mundo entero bajo el dominio de un "rey encubierto". La utopía aparece ya en voz de un poeta cuya recepción fue tan significativa en su tiempo para ameritar la inclusión en el Índex inquisitorial de 1581, a pesar de que para entonces no se conociera

\footnotetext{
${ }^{1}$ Textos tan tempranos como la Crónica General de Espanha de 1344 o la Crónica de Portugal de 1419 dan cuenta de esta batalla.

${ }^{2}$ El episodio de Ourique se narra en el Canto III, 41-54.
} 


\section{$68 \square$ LA CONSTRUCCIÓN MÍTICA DEL QUINTO IMPERIO PORTUGUÉS}

aún una edición en particular. Apoyadas en una lectura peculiar de la Biblia, las Trovas de Bandarra emplean un lenguaje profético en el que se combinan los símbolos cristianos y los judíos. Un ejemplo de ello es el gran león que el poeta distingue entre sus visiones, y que él mismo interpreta como este gran rey y pastor que sabrá dar caza a un jabalí, que en todo caso simbolizaría al enemigo común tanto de judíos como de cristianos, el musulmán:

\section{CLVI}

Todos terão um amor, Gentios como pagãos, Os Judeos serão Christãos, Sem jamais haver error.

\section{CLVII}

Servirão um so Senhor Jesu Christo, que nomeio, Todos crerão, que ja veio O Ungido Salvador.

\section{CLVIII}

Tudo quanto aqui se diz, Olhem bem as Profecias

De Daniel, e Jeremias, Ponderem nas de raiz. ${ }^{3}$

La cita de estas trovas da una idea tanto de las fuentes como de la intención profética del texto. En el Portugal católico del siglo XVI, Bandarra ve un mundo unificado bajo un mismo credo y bajo un mismo cetro: Jesucristo y el Rey Encubierto habrían de vencer al enemigo para crear un reino de paz donde el gentil y el pagano, el judío y el cristiano se tengan un gran amor.

Si el Milagro de Ourique pudiera carecer de crédito por tratarse de una leyenda oral, el texto de las Trovas representa una primera fuente documental en la tradición del mesianismo portugués. Además, la vigencia de las Trovas no solamente se mantuvo, sino que se vio reforzada por nuevos detonantes históricos, sin los cuales difícilmente se podría entender un hecho como la primera edición impresa, en la ciudad extranjera de Nantes, hacia el tardío año de 1644. En una Europa familiarizada con la imprenta, ¿qué pudo haber mantenido la inquietud del público por una obra como la de Bandarra? No su calidad literaria sino la fuerza discursiva del mensaje que portaba en tiempos duros, como los que se avecinaban para Portugal.

\footnotetext{
${ }^{3}$ Todos tendrán un amor / los gentiles y paganos / los judíos serán cristianos / sin jamás haber error. Servirán sólo a un señor / Jesucristo que aquí digo / todos creerán, pues ya vino / el ungido salvador. Todo cuanto dije aquí / miren bien las profecías / de Daniel, de Jeremías / y pondérenlas de raíz. (La traducción es mía.)
} 


\subsection{Hacer cumplir la profecía: desaparición y esperanza en Don Sebastián}

En 1554, cuando ya circulaban las Trovas entre el público portugués, murió el príncipe don Juan de Portugal, hijo del rey don Juan III. Tras las muertes prematuras de sus cuatro hermanos mayores, el fallecimiento a los dieciséis años del príncipe Don Juan consternó al reino de Portugal, porque el viejo rey Don Juan III no tenía más herederos, y su eventual deceso, pocos años posterior al del príncipe, significaría el final de la Dinastía de Avis y una crisis para la independencia del reino. No obstante, el príncipe había conseguido dejar embarazada a su esposa, de quien había de nacer un rey que se volvería leyenda: Don Sebastián, el Deseado.

Además de una formación jesuítica que fortaleció su espíritu de cruzada, a los oídos de este joven rey habrán llegado no sólo las trovas proféticas de Bandarra, sino numerosos relatos heroicos sobre las guerras de Reconquista e innumerables poemas panegíricos donde él mismo aparecía como paladín del catolicismo. Los tiempos dorados de las navegaciones de Vasco de Gama, el descubrimiento y conquista de Brasil, así como la expansión comercial del reino portugués en el lejano Oriente parecían quedar atrás; de modo que la crisis, la corta edad y la literatura de la que se vio empapado, a la que se agregó, en 1572, la publicación de la epopeya Os Lusíadas, serían detonantes para que el rey don Sebastián, en un arranque de obnubilación juvenil y sin haber dejado sucesores, se lanzara a una anacrónica cruzada contra los turcos en Marruecos (Soler, 2003: 374-379).

La desaparición y muerte del rey Don Sebastián en la batalla de Alcazarquivir (1578) generó —además de una grave crisis sucesoria y la cesión de la corona portuguesa a Felipe II de España - una leyenda: el rey Don Sebastián no había muerto y había de volver una mañana de niebla para recuperar la corona y la independencia de Portugal. Durante el periodo de resistencia de Portugal a la dominación española, esta leyenda constituyó el principal fundamento del nacionalismo portugués.

Para 1603, con el título de Paraphrase e concordância de algumas profecías de Bandarra, çapateiro de Trancoso, publicó João de Castro un libro donde los estratos primarios del Milagro de Ourique y las profecías de Bandarra quedaron fundidos con la leyenda del regreso — aún viable — del rey don Sebastián, el cual no sólo volvería para recobrar la corona y la independencia de Portugal, sino que, como anunciaba el trovador, se convertiría en el león vencedor de los turcos enemigos y fundaría el reino de paz.

Como se puede ver, hay una constante tendencia en los relatos portugueses de carácter nacional a proyectarse hacia el futuro. Y si bien la leyenda de Ourique y la del regreso del rey Don Sebastián pertenecen al repertorio de la oralidad popular, parece haber una necesidad de reforzar estos relatos a través de la autoridad de la escritura. Y aunque el caso de Bandarra ya ejemplifica esto, a pesar de tratarse de un poeta popular y de la prohibición inquisitorial — debida, en gran medida, al carácter judaizante de las Trovas -, los casos de Luís de Camões y del padre António Vieira permiten ver cómo 
la institución literaria, incluso la más culta y acreditada, también se permite la práctica del mesianismo a fin de oficializar las utopías nacionalistas.

\subsection{Mitificar la historia patria: Camões}

Hacia 1572, el poeta más importante para la historia de Portugal alcanzaba la cima de su posteridad con la publicación de su epopeya Os Lusíadas. Hombre de aventura y letras, pues participó de los viajes a la India que dieron fama y riqueza a su patria, Luís de Camões había emprendido la hazaña literaria de narrar en diez cantos en octavas reales los viajes de Vasco de Gama y el descubrimiento de la ruta marítima a la India. Sin embargo, el poeta no se limitó a eso: el Canto III es una narración sintética de la historia de Portugal desde las más antiguas raíces de la nacionalidad que se remontan a los tiempos prerromanos, donde el capitán lusitano Viriato supo resistir al poderío de los ejércitos latinos. El relato de Camões continúa por pasajes como el milagro de Ourique y la fundación del reino, para narrar después la historia de todos los próceres portugueses; su punto de llegada son sus propios tiempos, donde tienen cabida la crítica social y la alabanza del rey Don Sebastián, a quien fue dedicada la epopeya.

Recibida en tiempos de decadencia, aunque con el recuerdo de glorias recientes aún despierto, la epopeya consolidó el nacionalismo de los portugueses, quienes desesperaban históricamente por no ser confundidos con los españoles. Hasta el siglo pasado, el estado portugués seguía empleando la epopeya para reforzar el nacionalismo durante la dictadura de Oliveira Salazar; hoy permanece en la base de los programas de estudio. El 10 de junio de cada año, como conmemoración por la muerte del poeta se celebra el Dia de Portugal, de Camões e das Comunidades Portuguesas, una de las fiestas de carácter civil más importantes del país. De modo que, en nuestros días, se sigue confirmando el parecer de Teófilo Braga: Os Lusíadas es la "epopeya de la nacionalidad".

Dado que Camões fue contemporáneo del rey Don Sebastián, la profecía del rey encubierto no tiene cabida en la epopeya, pero sí lo tienen el espíritu de cruzada y la mitificación del portugués como hombre de mar y de aventura, la leyenda del milagro de Ourique con su proyección a futuro, y la revelación de la Máquina del Mundo en el Canto X, donde la nereida Tetis le muestra al capitán Vasco da Gama una representación del globo, que se puede leer entre líneas como promesa de posesión. De modo que la expansión imperial de Portugal no sólo estaba históricamente justificada, sino divinamente profetizada. A la manera de Virgilio con la Roma de Augusto, el Portugal de Don Sebastián debía prepararse para sus años de mayor grandeza.

Camões murió poco tiempo después de la derrota de Alcazarquivir, de la cual llegó a tener noticia. El gusto o el hábito portugués de mitificar la historia daría al escritor romántico Almeida Garrett el privilegio de matar a Camões junto con la patria: el destino de la epopeya y el de la nación portuguesa estarían indisolublemente ligados. 


\subsection{Recobrar la independencia y fundar el Quinto Imperio}

A la consternación por los fines, tan cercanos entre sí, de Camões, del rey Don Sebastián y de la independencia del reino, se agregarían afirmaciones como la del libro de João de Castro, que identifica al rey Don Sebastián con el rey encubierto de las Trovas, y la planteada en el Tratado dos cometas, de Manuel Bocarro Francês, que en 1619 anunciaba el resurgimiento de Portugal para el año de 1653 (Saraiva, 1992: 81). La pérdida de la independencia exacerbó la producción de textos nacionalistas en el llamado periodo de resistencia portuguesa, que tocaría su fin (no sin una importante participación geopolítica de Inglaterra) en 1640 cuando la independencia portuguesa fue recuperada.

Quizá todos estos hechos históricos y sus tejemanejes literarios no habrían bastado para el surgimiento de un topos de tan superior naturaleza como el Quinto Imperio: hacía falta la aprobación de la autoridad eclesiástica para dar validez a un discurso utópico semejante. Bandarra ya sustentaba sus Trovas en la lectura del Antiguo Testamento, sobre todo en los libros proféticos, pero sólo la habilidad teológica y retórica de un hombre como el Padre Vieira podría articular el mesianismo implícito en leyendas como la de Ourique y la del regreso del rey Don Sebastián con la escritura sagrada y, sobre todo, sólo una reputación como la que gozaba el orador hacia 1640 permitiría un atrevimiento semejante, pues en vez de condenar al judaísmo, según el espíritu de la Contrarreforma, pretendía unirse con él.

El pasaje bíblico que fundamenta la utopía del Quinto Imperio es bastante conocido: en el segundo capítulo del Libro de Daniel, el rey Nabucodonosor tuvo un sueño que le inquietó el espíritu. Llamó a los magos y astrólogos para que lo interpretaran; sin embargo, ninguno de ellos pudo hacerlo, porque el rey no consiguió revelarles su sueño, fuera por olvido o por desconfiar de ellos; además, amenazó con hacerlos pedazos y destruir sus casas si no lograban explicarle el sueño. Los magos y astrólogos intentaron mostrar al rey la necedad e imposibilidad de lo que pedía, pero Nabucodonosor no transigió y mandó matar a los "sabios" de la ciudad. Al enterarse del bando que los condenaba, Daniel pidió tiempo al rey para resolver sus demandas y apeló a la misericordia de su Dios, quien le reveló el sueño y su significado. El rey había soñado con una enorme imagen (aunque la Escritura no dice que sea una imagen humana, esto parece entenderse por su descripción) de aspecto terrible: su cabeza es de oro; su pecho y brazos, de plata; su vientre y muslos, de bronce; las piernas, de hierro, y los pies, en parte de hierro y en parte de barro cocido. Repentinamente una piedra hirió la imagen en los pies y poco a poco fue desmenuzando todas las otras partes de la estatua hasta hacerlos polvo. El viento se levantó y no quedó nada de la imagen, en cambio, de la piedra se hizo un monte que llenó la tierra.

La explicación de Daniel fue que los cuatro metales correspondían a cada uno de los cuatro imperios que se sucederían en el mundo. La piedra era el reino de Dios, que pulverizaría los otros cuatro y los sustituiría para siempre. Sin embargo, la Escritura sólo hace corresponder uno de los imperios con los que habían de existir históricamente: 
la cabeza de oro representaba, según Daniel, al imperio asirio-babilónico de Nabucodonosor. Las posteriores interpretaciones del pasaje bíblico han hecho coincidir la plata con el imperio persa, el bronce con el greco-macedónico y el hierro con Roma, del cual la Europa de Vieira es una prolongación. Las interpretaciones han sido variadas, por ello no debe extrañar que se haya prestado a una particular por parte del teólogo portugués, para quien el Quinto Imperio será el imperio de la Iglesia, un imperio de desarrollo completamente espiritual.

El artículo de Saraiva polemiza con otras interpretaciones del pasaje bíblico, especialmente con la del rabino Menasseh ben Israel, conocido de Vieira y con el cual documenta Saraiva un intenso diálogo teológico sobre dos aspectos cuya interpretación como indicios de que el Quinto Imperio está cerca fueron motivo de polémica entre ambos religiosos: el regreso de las tribus y el problema del Mesías.

No abundaremos en tal polémica. Para ello remito al artículo del investigador portugués, pues interesan otros aspectos contemporáneos al debate, como la leyenda del pueblo escondido de las batuecas, que estaba en España desde la conquista musulmana de Al-Ándalus y que volvió a descubrirse en un supuesto estado semisalvaje hacia los tiempos de Colón. Hechos como éste daban a Vieira razones para sospechar que las tribus perdidas podrían estar en algún lugar de América, y que pronto volverían para colaborar en la fundación del Quinto Imperio. Por otra parte, hemos explicado ya cómo el ideario portugués tenía preparado el terreno para la vuelta de un Mesías, encubierto bajo el halo profético de Bandarra y la leyenda del rey Don Sebastián. No olvidemos tampoco que la formación jesuítica del padre Vieira bajo el imperativo de la propaganda fide y la tradición naval de pueblo portugués, recién consolidada por Camões, eran susceptibles de entrar en los silogismos del teólogo como índices claros de que lo mejor estaría por llegar; y aunque hoy estos mesianismos puedan movernos a risa, tampoco debemos soslayar el fin práctico y político que el padre Vieira tenía en mente: aprovechar los capitales de los judíos exiliados durante la dominación filipina.

Los argumentos teológicos no son de menor importancia: para el establecimiento del Quinto Imperio era necesario que judíos y cristianos se unieran bajo el Mesías. Para Vieira, como para muchos simplificadores de la fe judaica, el único "error" de los rabinos era no dar crédito a que el Mesías era Jesucristo. Convertirlos a la Fe era una tarea urgente, y reabrirles las puertas de Portugal aparecía como un acto de generosidad introductoria a la bondad de las enseñanzas de Cristo, como si la milenaria tradición del pueblo de Abraham careciera de lecciones sobre la crueldad y la arbitrariedad de los imperios humanos, y como si hubieran olvidado también su carácter errante. Como ocurre con las utopías cuando intentan llevarse a la práctica, el brillo propio de la idealización impide ver con cabalidad la dimensión de los obstáculos. La grandilocuencia del título completo de la obra lo confirma: História do Futuro. Esperanças do Portugal, Quinto Império do Mundo. Vieira intentaba aplicar con los expatriados judíos la misma dialéctica que se aplicaba a los pueblos subyugados de las colonias ultramarinas.

Saraiva apunta que Vieira comenzó a escribir esta obra al otro lado del océano, ocupado con la recién creada Companhia Geral do Comércio do Brasil, donde la utopía 
daba atisbos de ser realizable. No será casualidad que después del fracaso de sus planteamientos frente al poder del Santo Oficio, de su proceso, de su exilio en Roma, donde reafirmó su mesianismo y sus ataques a la Inquisición, el padre Vieira haya decido establecerse definitivamente en Brasil, donde había incubado la idea y adonde volvió para terminarla de no habérsele interpuesto su propia finitud: História do Futuro. Esperanças do Portugal, Quinto Império do Mundo es una obra inconclusa, el fracaso de un hombre que había triunfado en todo el orbe católico por la grandeza, más que nada, de su oratoria: un portugués como los que abundan en la literatura de éste hoy pequeño país que mira al mar con saudades del pasado.

\section{En busca del Imperio perdido. El mesianismo en la modernidad portuguesa}

El legado de Bandarra, Camões y Vieira tendría eco en la literatura portuguesa moderna. Como ocurrió con las literaturas de otros países europeos, las búsquedas estéticas del Romanticismo contribuyeron a la revaloración de las tradiciones populares y del pasado histórico en sus más hondas raíces fundacionales a fin de exaltar los nacionalismos. En un texto paradigmático, Eduardo Lourenço revisa los distintos caminos que los escritores portugueses del XIX e inicios del XX siguieron para afirmar la identidad nacional. Para él, la obra que inaugura este periodo de autognosis es el poema Camões (1825) de Almeida Garrett - cuyo título ya revela la importancia del poeta épico en la tradición nacionalista de Portugal - y el cierre es Mensagem (1935), importante poema donde Fernando Pessoa consigue concentrar el capital simbólico de un Portugal que, en un largo proceso de transición entre la monarquía y el republicanismo, ha sobrevivido a un duro periodo de guerras civiles e interrogantes sobre el destino patrio (Lourenço, 2000: 84-85).

No será hasta Pessoa que el núcleo utópico del Quinto Imperio vuelva a ser planteado de manera directa, aunque con un importante cambio de sentido. Para llegar a él fue necesario un accidentado proceso de valoración e interrogación tanto de la historia como del destino de Portugal a través de uno de los mitos ligados más directamente a la utopía del Quinto Imperio, el de Don Sebastián. Siguiendo el trayecto de Lourenço, explicaremos brevemente las transformaciones valorativas más significativas que el mito sebastianista sufrió en el trayecto entre Almeida Garrett y Fernando Pessoa.

\subsection{Almeida Garrett, Frei Luís de Sousa}

Después de una juventud políticamente agitada, en la que se vio forzado a dos exilios, Almeida Garrett se estableció en Portugal y participó activamente en las políticas públicas, principalmente en las relacionadas con las actividades educativas y culturales, para las que lo facultaba su ya ganado renombre como escritor. Con la obra Frei Luís de Sousa (publicada y representada entre 1843 y 1844) el autor forma parte de la 
renovación del teatro nacional, pero, sobre todo, cuestiona el pasado y el futuro de la patria a través de un peculiar planteamiento del sebastianismo: Madalena, uno de los personajes protagónicos, está casada en segundas nupcias con don Manuel de Sousa. Su anterior marido, don João de Portugal, fue con el rey Don Sebastián a la batalla de Alcazarquivir y, como él, tampoco regresó hasta que se le dio por muerto tras veinte años de esfuerzos por rescatarlo. Madalena ha intentado rehacer su vida, obteniendo en María el angustioso fruto de su segundo matrimonio; angustioso porque nunca ha logrado sacudirse los temores de que su primer marido siga con vida en alguna parte. Y en efecto, tal como profetizaba Bandarra que había de volver el rey que establecería el Quinto Imperio, vuelve encubierto don João de Portugal a su palacio. Este regreso hace de María una hija ilegítima, una bastarda, que muere de vergüenza en cuanto se entera de su condición. Por su parte, don João de Portugal, al ver irremediablemente perdido su lugar en la vida de Madalena, desaparece tan misteriosamente como volvió.

Si se considera a Madalena como el presente de la patria y a María como el futuro, el regreso de don João-Sebastián tiene un signo evidentemente negativo. La tragedia de Portugal estriba en la relación nostálgica con su pasado imperial idealizado. Avergonzados del crimen que reconocen en su unión ilegítima, Manuel y Madalena se retiran a la vida monástica e inician una vida nueva a la que ya no asistimos como lectores: don Manuel de Sousa se convierte en Fray Luis de Sousa, reconocido cronista y hagiógrafo. Las lecturas de este desenlace son múltiples, pero cabe sobre todo la crítica a una patria que no deja de mirar hacia el pasado y espera demasiado de un futuro que ese mismo pasado anula. Don João-Sebastián regresa resignado a las tinieblas, al mundo meramente legendario adonde pertenece.

Para los años en que escribe Garrett, otros autores, como Alexandre Herculano, ya pensaban en una reescritura más seria de la historia de Portugal, desentramando algunas formas tradicionales de interpretación histórica (las llamadas cãs de mentira que eran tenidas como venerables). Considerados ambos como escritores romántico-nacionalistas, Garrett y Herculano encabezaron una generación de intelectuales que ejemplificó, con este modo de leer el sebastianismo y otros mitos portugueses, ${ }^{4}$ el cambio de rumbo que la cuestión de Portugal estaba experimentando.

Eduardo Lourenço habla después de la importancia que tuvo la llamada Generación del 70 en el proceso de autognosis de Portugal. Sin embargo, consideramos que debido a sus propias búsquedas estéticas e ideológicas — que atacaban duramente los $p a$ trioterismos-, esta rebelde, prolífica e importantísima generación de escritores dejó en segundo plano tanto las utopías como los mitos de la nacionalidad lusitana. El sebastianismo seguirá siendo criticado sin llegar a constituir el asunto central de alguna obra representativa de este grupo de escritores.

\footnotetext{
${ }^{4}$ Otro mito que Herculano deconstruye en su História es el de la existencia de una raza "lusitana", y lo hace a través de una revisión de los grupos que habitaron la península antes de los romanos y sus interacciones durante de la Edad Media, periodo en el que comenzaría la formación del estado portugués.
} 


\title{
2.2. António Nobre, O Desejado
}

La aspereza crítica de la Generación del 70 provocó reacciones tanto en el público como en la intelectualidad del país. En particular, la crítica a cuestiones como el sebastianismo impulsará en poetas como António Nobre una búsqueda casi desesperada por asir el destino de Portugal a una esperanza, porque si la situación portuguesa para la década de los ochenta era ya difícil, el Ultimato inglés de $1890^{5}$ sumiría a la nación en una honda crisis de legitimidad política que marcaría el camino hacia la proclamación de la Primera República.

Como para cerrar una era, António Nobre muere a los treinta y tres años en el año de 1900, luego de una curiosa trayectoria de vida en la que representó los papeles de mártir y de iluminado. Dos años después, se publica de manera póstuma el libro Despedidas, donde se incluye un sentido y por momentos dramático poema que lleva por título $O$ Desejado. El albor del nuevo siglo anuncia a Don Sebastián:

\author{
Esperai, esperai, ó Portugueses! \\ Que ele há de vir, um dia! Esperai. \\ Para os mortos os séculos são meses, \\ Ou menos que isso, nem um dia, um ai. [...] \\ D. Sebastião, rei dos desgraçados, \\ D. Sebastião, rei dos vencidos, \\ El-Rei dos que amam sem ser amados, \\ El-Rei dos gênios incompreendidos. ${ }^{6}$
}

El poeta se reconoce en estos últimos dos versos y extiende su sufrimiento a una nación descobijada, pero también extiende a ella una esperanza que toca nuevamente el mesianismo, uno simbólico, si se quiere, o uno místico que trasluce en la letanía de los últimos cuatro versos como una invocación. Más adelante, en un muy logrado movimiento enunciativo, el poema retoma la primera persona para fundir en una sola voz la suya propia, la del rey Don Sebastián y la de los personajes ficticios Anrique y Dom Manoel Dos Sofrimentos, que aluden a dos significativos reyes de Portugal, al mismo tiempo que establece un diálogo con Teresa, ${ }^{7}$ de quien recibe en líneas como las siguientes la clave de su salvación:

${ }^{5}$ El 11 de enero de 1890 recibió el gobierno portugués un "Memorando" del gobierno británico donde se le conminaba a retirar las fuerzas militares de sus colonias africanas en las regiones de Angola y Mozambique. Bajo el pretexto de un conflicto con nativos africanos, pero con importantes intereses en la explotación de minas de diamantes en el sur de África, este evento complicó la ya de por sí desigual relación entre dos países históricamente asociados.

${ }^{6}$ ¡Esperad, esperad! ¡Oh, portugueses! / ¡Que él ha de venir, un día! ¡Esperad! / para los muertos los siglos son meses, / o menos que eso, ni un día, un ay / Don Sebastián, rey de los desgraciados, / Don Sebastián, rey de los vencidos, / el rey de los que aman sin ser amados, el rey de los genios incomprendidos. (Traducción mía.)

${ }^{7}$ Los personajes de Anrique y Teresa aluden a los fundadores de Portugal, el conde Don Henrique y su esposa Teresa o Tareja (en galaico-portugués). Este diálogo entre los esposos recuerda la poesía de tradición mística, pero así como se identifican en una sola las voces del poeta, Anrique, Don Manoel y Don Sebastián, 
Anda, meu filho: vai dizer baixinho

A esse povo do Mar, que é teu irmão,

Que não fraqueje nunca no caminho,

Que espere em pé o seu D. Sebastião [...]

Anrique, vai gritar por essa rua

—Virá um dia o "Sempre-Desejado"!

Deu a vida por vós, Tu, dá-lhe a tua,

Esquece nele todo o teu passado.

Procura bem Anrique, em Portugal;

Procura-o na flor das primaveras,

Procura-o na sombra do olival;

Procura à luz de todas as quimeras... ${ }^{8}$

La identificación de Don Sebastián con el Cristo del Calvario ahora se revela como un evangelio, pues esta venida es un imperativo teleológico en la existencia de cada portugués. No es ya la espera pasiva de la mañana con neblina que envolvería su regreso, sino una búsqueda activa: hay que buscar a Don Sebastián en Portugal, en lo placentero de las flores y en lo laborioso y sombrío de los olivares que dan tanto sentido a la existencia ${ }^{9}$ como las quimeras de que la nación se alimenta y en las que se reconoce.

Podría sorprendernos el modo en que las temáticas nacionalistas, pensadas en un nivel metaliterario, proyectan su significatividad inclusive hasta la crítica literaria del siglo Xx y se insertan en el debate sobre la canonización de determinadas obras y autores al momento de escribir la historia literaria de un país. La polémica entre Augusto da Costa Dias y João Gaspar Simões al respecto de António Nobre es una muestra de ello: mientras que el segundo defendía al poeta como una figura indispensable de la literatura "nacional", el primero no dejaba de señalar que, a partir de la obra de Nobre, la modernización literaria comenzada con Garrett y Herculano da marcha atrás, ya sea por las dificultades del contexto histórico, ya por una ideologización que la pequeña burguesía lusitana perseguía, o por ambas razones ( $c f$. Costa Dias, 197: 11-50.) Este "retroceso" - por así llamarlo, a riesgo de caer en cierto "evolucionismo" literario — se hace aún más evidente cuando historiadores de la literatura portuguesa tan autorizados

el poema juega también con la identificación entre Teresa y María, lo que multiplica las interpretaciones. En el caso de Don Manoel hay una clara ironía en el poema: la figura del rey don Manuel de Portugal, que protagonizara los hechos con que Portugal se consolidó como imperio y potencia naval, sufre una inversión de signo y pasa a ser D. Manoel dos Sofrimentos, hombre viejo y desnudo con quien se funde el poeta en un proceso más de identificación.

${ }^{8}$ Anda, hijo mío: ve a decir bajito / a ese pueblo del Mar, que es tu hermano, / que no flaquee nunca en el camino, / que espere en pie a su Don Sebastián.

Anrique, ve a gritar por esas calles / ¡Vendrá un día el "Siempre-Deseado”! / Dio la vida por ti, tú dale la tuya, / olvida en él todo tu pasado. / Busca muy bien, Anrique, en Portugal; / Búscalo en la flor de primavera, / Busca a la sombra del olivar. / Busca a la luz de todas las quimeras.

${ }^{9}$ No olvidemos que Portugal es, por tradición, un importante productor y exportador de aceite de oliva. 
como Saraiva y Lopes engloban bajo el término correntespassadistas las obras de autores contemporáneos y posteriores a Nobre, entre los cuales se barajan términos como: neo-Garrettismo, lusitanismo, nacionalismo y posteriormente saudosismo y Renascença Portuguesa, las cuales son cercanas en las intenciones literarias aunque se separen en lo ideológico (Saraiva, 2000: 960). A estas últimas dos había de dar eco la instauración de la Primera República a partir de 1910.

\subsection{Teixeira de Pascoaes, Arte de Ser Português}

Es un hecho curioso que hacia 1915, la declarada vinculación del movimiento saudosista con el gobierno de una república — que en aquel entonces representaba el mayor logro del pensamiento progresista - diera como producto un libro que, visto desde la actualidad, cae en tan exagerado nacionalismo y en tal mistificación de figuras y mitos portugueses, que podría caberle el calificativo de reaccionario. Pese a ello, el Arte de ser português de Teixeira de Pascoaes pudo ser una de las primeras tentativas por cerrar el ya referido proceso de autognosis señalado por Lourenço.

Al dedicar su texto a la juventud (À mocidade), el autor advierte la intención doctrinal del libro (ele contém a boa e sã doutrina portuguesa). Después de casi cuatro siglos -iniciando en el XVII cuando Vieira lo usaba para difundir el pensamiento eclesiástico, pasando por los enardecidos discursos de los jacobinos franceses y de los republicanos en algunas otras naciones de Europa - el término doctrina volvió a resonar en Portugal por conducto de Pascoaes. A más de medio siglo de que ciudades como Londres, París, Viena, Filadelfia y Melbourne pregonaran el cosmopolitismo global en las exposiciones universales, coronadas con la Torre Eiffel; más de una década después de que Estados Unidos arrebatara las últimas colonias a la malherida España, a casi medio siglo de que un portugués (Eça de Queiroz) testimoniara en Suez la inauguración de la ruta marítima anti-lusíada por excelencia, otro portugués blandía su Arte de ser portugués como un evangelio. Frente a estos anuncios de la globalidad contemporánea, el texto de Pascoaes podría parecer ridículo; sin embargo, hay que entenderlo, primero, como resultado de un proceso histórico interior culminado con la instauración de la Primera República Portuguesa — con todos los optimismos que tales acontecimientos acarrean-y, segundo, como un texto empapado de ideas nacionalistas en las que no sólo Portugal estaba interesado: cuando el libro de Pascoaes ve la luz, las vicisitudes de la Primera Guerra han involucrado al país; los totalitarismos están desarrollando sus programas en Italia, en Alemania, en la muy pronto revolucionaria Unión Soviética; es la Europa de Marinetti, la que vislumbraba el futuro en utopías republicanas o socialistas, en estados nacionales sólidos; los ismos izaban sus banderas en los manifiestos. Hay una fiebre de "modos de ser".

Por otra parte, Portugal tampoco podía mantenerse ajeno al drama de la globalidad, pues conservaba extensos territorios en África y algunos puntos de comercio en Asia, de modo que, a pesar de la humillación del Ultimato y de la irreparable pérdida de 
Brasil casi un siglo atrás, el imperio podía soñar con mantenerse en pie bajo la guía de un nuevo gobierno que hiciera realidad los ideales republicanos. Por conducto de esta doctrina, Pascoaes intenta conciliar al portugués con su identidad a través de la formulación de un ideario y una axiología que por momentos se mueven en niveles muy altos de abstracción (y de generalización, diríamos hoy). Desde el inicio, Pascoaes dialoga con los usuarios potenciales del texto: alumnos y maestros de un hipotético sistema republicano de educación. Para ello pone en la base de su doctrina los conceptos de Raza, Patria y Destino, todos ellos con mayúscula, dado el alegorismo y grandilocuencia de un texto de semejantes vuelos. Pascoaes presenta del siguiente modo el Destino de la Patria: "As Descobertas foram o início da sua Obra. Desde então até hoje tem dormido. Desperta, saberá concluí-la... ou melhor, continuá-la, porque o definitivo não existe" (1978: 18).

Este arranque encierra muchas de las significaciones más frecuentes del texto. Hacerla pasar por un sueño es una forma peculiar de anular la historia moderna de Portugal: sin fechas, años, ni nombres concretos, los descubrimientos se vuelven una abstracción, se les sustrae el carácter histórico y se les valida como único hecho consciente de la Patria. Pero ni al crítico actual ni a los lectores contemporáneos del texto podía pasárseles por alto el estrecho vínculo entre los descubrimientos y el imperialismo colonial que, desde luego, el texto sí soslaya, junto con el fracaso del proyecto imperial en las regiones asiáticas.

Además de los ya mencionados, en su definición de la "portugalidad", Pascoaes pasa revista a conceptos como Herencia, Tradición, Lengua, Ley Suprema, Familia, Munícipe, Paisaje; inclusive el Mesianismo es desarrollado como parte del Ser Portugués y todos ellos consiguen mayor solidez cuando se vinculan a las ideas de Saudosismo y Sebastianismo, al ser conjugados en el capítulo final del libro bajo el título de "O nosso idealismo". Ahí se hace patente que, si la gran Obra de la patria fueron los descubrimientos, los hechos de Alcazarquivir marcan el inicio del largo sueño de la patria: "Desbaratado, em Alcácer Quibir, [Portugal] apareceu ao Povo em fantasma, como Jesus aos Discípulos depois da Tragédia do Calvário" (139).

La analogía entre el Don Sebastián fantasmal y el Jesús resurrecto revela el hilo sebastianista que conecta a Pascoaes con António Nobre. Como un estadio anterior y con tono elegíaco, la voz poética del texto de Nobre envía a buscar a un Don Sebastián equivalente a Cristo muerto: "deu a vida por vós, Tu, dá-lhe a tua, / esquece nele todo o teu passado" (vid. p. 14). En cambio, Pascoaes ofrece una resurrección: "Se anossa grandeza morreu materialmente, foi para ressurgir em espírito. O Sebastianismo, sendo a expressão mítica de nossa dor, é já, em sombra nocturna, o futuro sol da Renascença” (139). El "sentimiento saudosista" se explica como una esperanza en el más cristiano y el más sebástico de los sentidos. Páginas atrás el autor ha presentado el vocablo saudade entendido como expresión intraducible del genio portugués. En este punto, una vez planteado el sebastianismo del espíritu, opone Pascoaes al utopismo tradicional y a la saudade entendida como nostalgia dolorosa por el pasado, un idealismo verdadero y una saudade libertadora: “À utopia dos nossos maiores que só acre- 
ditavam na Matéria, numa vil materia obediente às leis escritas, reformável por meio de portarias e decretos, debemos opor o verdadeiro idealismo: a crença no Espírito como sendo o fim divino da Matéria, a Necessidade convertendo-se em Liberdade" (145).

Éste quiso Pascoaes que fuese, tal vez, el idealismo de la flamante República Portuguesa que había de dejar atrás el imperio colonial para convertirse en un imperio del espíritu, una especie de Quinto Imperio de mayor duración que no estaría sujeto a la vanitas de lo material, tal vez el imperio que Fernando Pessoa intentará construir sobre las bases de la cultura portuguesa.

\subsection{Fernando Pessoa: Mensagem y el imperio cultural}

Frente a los fenómenos de la heteronimia, de la personalidad fragmentada y del genio poético ha pasado a segundo plano, sobre todo para el público internacional, el único libro de poemas que Fernando Pessoa dio a la luz con su nombre ortónimo mientras vivió. Para el título, el autor debió elegir entre el nacionalismo obvio de Portugal y el evangelismo de Mensagem. La proyección del texto hacia su significación social y mesiánica debió determinar su preferencia por el segundo, pues el texto había de actualizar, cuando no de sustituir la intención condensadora de los símbolos lusitanos que hizo de Os Lusíadas la epopeya nacional portuguesa.

Poema de largo aliento y compuesto a lo largo de casi veintiún años, Mensagem se compone de tres partes donde se conjuntan los símbolos, los mitos y la esperanza de Portugal en el futuro. El lenguaje simple pero lleno de referencias históricas, literarias y legendarias demuestra el conocimiento y el gusto de Pessoa por la poesía europea reciente que lo acerca a las poéticas de la poesía pura y al Simbolismo; sin embargo, en vez de los símbolos universales empleados por los poetas franceses, Pessoa se inclina por las figuras representativas de su nación.

En la primera parte, “Os brasões" (Los blasones), analiza poéticamente el escudo de la bandera portuguesa. El poeta pasa revista a la historia más remota de Portugal, que en algunos casos se pierde en leyendas como la del Ulises homérico, supuesto fundador de Lisboa, o la del héroe lusitano Viriato, que resistió a la avanzada del imperio romano. A la leyenda sigue la exaltación de figuras medievales de la fundación del reino, como Afonso Henriques o el rey Don Duarte, así como de los reyes y nobles portugueses que a finales de la Edad Media promovieron tanto el espíritu de cruzada como la expansión ultramarina del reino.

Bajo el subtítulo de "Mar português" se reúnen en la segunda parte los poemas que exaltan aquello que Teixeira de Pascoaes decía ser el inicio de la obra de la Patria portuguesa, los descubrimientos. En esta parte la intertextualidad con la epopeya de Camões se vuelve más evidente a través de las figuras del mar y de navegantes como Vasco da Gama. 


\section{$80 \square$ LA CONSTRUCCIÓN MÍTICA DEL QUINTO IMPERIO PORTUGUÉS}

Pero es la tercera parte la que más nos interesa, puesto que el subtítulo de "O Encoberto" remite nuevamente al mito de Don Sebastián, que será explotado con artificios que proyectan el poema hacia lo evangélico y justifican la elección del título general, Mensagem. Destaca la presencia de una composición llamada “Quinto Império”, la cual aparece inmediatamente después de otra en la que Don Sebastián grita a los portugueses: Sperae! (¡esperad!). En "Quinto Império” podemos leer las siguientes estrofas:

$$
\begin{aligned}
& \text { E assim, pasados os quatro } \\
& \text { tempos do ser que sonhou, } \\
& \text { a terra será theatro } \\
& \text { do dia claro, que no atro } \\
& \text { da erma noite começou. } \\
& \text { Grecia, Roma, Cristiandade, } \\
& \text { Europa -os quatro se vão } \\
& \text { para onde vae toda edade. } \\
& \text { Quem vem viver a verdade } \\
& \text { Que morreu D. Sebastião? }
\end{aligned}
$$

Si en el poema precedente Don Sebastián pide a los portugueses que esperen por él, es porque la promesa de Quinto Imperio reaparece, aunque con una actualización: los imperios persa y babilónico se occidentalizan y se sustituyen por Grecia y Roma, el cristianismo puede representar la Edad Media y Europa, la Modernidad. ${ }^{10}$ Aunque la mutación del mito parezca anodina, no debe verse como casual. Para Pessoa estos cuatro imperios previos representan la herencia cultural de Portugal y, ante el desastre material del país, es justamente en este sentido que al poeta le interesa rescatar un Quinto Imperio simbólico, sostenido por la riqueza cultural lusitana. A diferencia de sus predecesores modernos: Garrett, Nobre y Pascoaes, Pessoa no limita el mesianismo a la figura de Don Sebastián, sino que la incluye en un proceso de mitificación más complejo que raya en el esoterismo y la profecía, como puede notarse en la siguiente subsección de esta tercera parte ("O Encoberto"), que está conformada por tres poemas agrupados bajo el subtítulo "Os avisos", y dedicados, en orden cronológico a Bandarra, y a António Vieira; el tercero, sin subtítulo, alcanza mayor significatividad, pues está escrito en primera persona y en tiempo presente: Pessoa mismo se asume como responsable de este tercer "aviso" que resulta cabalísticamente definitivo.

Gestos como el anterior permiten afirmar que en Mensagem se materializan poéticamente las grandes preocupaciones del autor sobre el destino de Portugal, pues basta una breve revisión de los muchos documentos que dejó inéditos para percatarnos de la

\footnotetext{
${ }^{10}$ Llama la atención que en la entrevista "Portugal, Vasto Império-Uminquérito nacional”, Pessoa identificase este imperio moderno con Inglaterra: "Até hoje, adentro da civilização que vivemos, tem havido quatro impérios —o grego, o romano, o cristão, e o inglês (que não o britânico, que é império em outro, e mais baixo, sentido)" (Pessoa, 1979: 100).
} 
recurrencia de estas ideas y de la necesidad que Pessoa veía de retomar o refundar los mitos que permitieran una identificación e incluso un quehacer nacionales. En una entrevista de 1926, se le pregunta a Pessoa si es posible levantar la moral de una nación a través de un aparato propagandístico y responde con estas palabras:

Hás ó uma espécie de propaganda com que se pode levantar o moral de uma nação — a construção ou renovação e a difusão consequente e multímoda de um grande mito nacional. De instinto, a humanidade odeia a verdade, porque sabe, com o mesmo instinto, que não há verdade, ou que a verdade é inatingível. O mundo conduz-se por mentiras; quem quiser despertá-lo ou conduzi-lo terá que mentir-lhe delirantemente, e fá-lo-á com tanto mais êxito quanto mais mentir a si mesmo e se com penetrar da verdade da mentira que criou. Temos, felizmente, o mito sebastianista, com raízes profundas no passado e na alma portuguesa (Pessoa, 1979: 100).

Para 1926, Pessoa ya lleva tiempo pensando en la contribución que la literatura puede hacer a la afirmación de un sentimiento nacional, y consciente del peso que el sebastianismo y el Quinto Imperio tienen en ello, busca consolidar esta tradición mítica al privilegiarla por encima de otras, de cuño eclesiástico, como la de Nossa Senhora de Fátima.

O verdadeiro patrono do nosso País é esse sapateiro Bandarra. Abandonemos Fátima por Trancoso. [...] Esse humilde sapateiro de Trancoso é um dos mestres da nossa alma nacional, uma das razões de ser da nossa independência, um dos impulsionadores do nosso sentimento imperial. [...] O Bandarra, símbolo eterno do que o Povo pensa de Portugal. Que Portugal tome consciência de si mesmo. [...] Repudio, por isso, tudo quanto seja missões religiosas, ou tudo quanto tente falar a um homem, como verdade, uma linguagem que ele não pode compreender [...] Se há que haver religião em nosso patriotismo, extraiamo-la desse mesmo patriotismo. Felizmente temo-la: o sebastianismo (52).

Frente a la realidad portuguesa, quizá una de las mayores complicaciones de Pessoa radicaba en la justificación de un sueño imperial que impulsara la "Renascença nova" que ya veía el poeta en autores como Pascoaes, quien ya había dado el primer paso al definir en su Arte de ser português un modo de espiritualidad nacional. Si el Quinto Imperio había de erigirse, lo haría sobre las bases de la cultura y de la lengua portuguesas. De ahí que el ciclo de Mensagem cierre en tiempo presente y que sea su propia voz, la del Supra-Camões que dio el tercer aviso, la que dé la Hora tan ansiada del regreso de Don Sebastián:

Tudo é incerto e derradeiro,

Tudo é disperso, nada é inteiro.

Ó Portugal, hoje é nevoeiro...

É a Hora! 


\section{$82 \square$ LA CONSTRUCCIÓN MÍTICA DEL QUINTO IMPERIO PORTUGUÉS}

La incertidumbre que comunican los versos, la incertidumbre de los hechos portugueses de los últimos siglos y también de los últimos años, posteriores a la proclamación de la inestable Primera República — que en dieciséis años vio pasar más de cuarenta cambios de gobierno para luego derivar en el dictatorial Estado Novo- se materializan poéticamente en la imagen de la neblina que satisface la inclinación de Pessoa por los contrasentidos y las paradojas: el signo negativo de la niebla como incertidumbre se invierte para indicar el deseado regreso de Don Sebastián. El simbolismo de esta imagen tiene también alcances religiosos si se piensa en sus vínculos con la tradición de las sagas artúricas y la demanda del Santo Graal, vínculos que el poeta ha hecho explícitos en otro poema de esta última sección:
Vem, Galaaz com pátria, erguer de novo, mas já no auge da suprema prova, a alma penitente do teu povo à Eucaristia Nova.
Mestre da Paz, ergue teu gládio ungido, Excalibur do Fim, em jeito tal que sua Luz ao mundo dividido revele o Santo Graal!

(1993: 69)

Con la fusión de Don Sebastián y Galaaz, el caballero puro, la mañana de nevoeiro marca la hora de Portugal, la hora de la revelación y el inicio del Quinto Imperio. A diferencia de lo que ocurre con los lectores de Pessoa fuera de Portugal, a quienes el "mensaje" no estaba destinado, la recepción de este poema en el país fue llevada a la institucionalización. Este proceso comienza por la concurrencia del poeta, con el único libro en portugués que consiguió tener organizado, al premio Antero de Quental que organizaba el Secretariado da Propaganda Nacional en los primeros años del Estado Novo.

Paradójicamente, la proximidad de las fechas puede conducir a un equívoco: ¿si Pessoa publicó su única y más elaborada obra en portugués con la anuencia de las instituciones del nuevo régimen, se le puede acusar de colaboracionismo? Gracias a la filología hoy sabemos que no. La exhaustiva revisión del archivo y la correspondencia llevada a cabo por estudiosos como José Augusto Seabra han aclarado la posición de Pessoa frente al salazarismo:

Pessoa insinua assim que, além de um facto literário, a publicação de Mensagem constituiu igualmente um facto patriótico de transcendente importância. Na verdade, segundo o poeta, ela «coincidiu [...] com um dos momentos críticos (no sentido original da palavra) da remodelação do subconsciente nacional». Remodelação que não se confundia para ele, com o «nacionalismo» ideológico e político do "Estado Novo", de que pela mesma época começava a denunciar e a satirizar o vezo tendencialmente totalitário (Pessoa, 1993: XXXII). 
Si cupiera ironizar con esta obra que, según Eduardo Lourenço, cierra el ciclo de la autognosis de Portugal, se diría que la mañana de niebla anuncia a un Don Sebastián que supo llevar la estabilidad al país no sin pagar el alto costo del militarismo, el fascismo, la censura y un empecinamiento en la política colonialista que, tras una eternidad de cuarenta y un años, marcaría la hora final a todos los sueños imperiales de la patria portuguesa.

La evolución del mito del Quinto Imperio tanto en la mentalidad popular como en las más elaboradas manifestaciones letradas de Portugal permite confirmar, con Roland Barthes, que los conceptos míticos tienen como característica principal su capacidad de ser apropiados y alcanzar significaciones históricas bien definidas: leyendas como la de Ourique, mezcladas con discursos institucionalizados como el historiográfico y el religioso, permiten el surgimiento de una poesía popular de tono profético como la de Bandarra; cuando la significación contenida en ella se reviste de tal importancia que los escritores cultos la valoran, son ellos quienes la presentan como vehículo de identidad nacional en tiempos críticos. No es casual en el caso portugués que el mito tenga sus orígenes más remotos en un pasaje bíblico (Quinto Imperio) y en la revelación a un rey (Ourique), como tampoco lo es que el héroe mítico sea también un rey, pues estas incidencias ayudan a demostrar el vínculo entre lo sagrado y lo profano que Mircea Eliade detectó en sus estudios sobre los mitos. En los tiempos complicados de la historia profana, la identidad nacional ha de entenderse como un repertorio de símbolos y prácticas sagradas que han de preservarse para que el pueblo llegue a su destino, que ha de cumplirse, no en el mismo plano temporal de la historia profana, sino en el intemporal y grandilocuente de una historia construida como sagrada.

\section{Obras citadas}

BANDARRA, Gonçalo Anes. Trovas do Bandarra. Web: 14 de julio de 2016. <http:// www.gutenberg.org/files/20581/20581-8.txt>.

BARTHES, Roland. 2001. Mitologías. Trad. Rita Buongermino y Pedro de SouzA. Río de Janeiro: Bertrand Brasil.

Braga, Teófilo. 1981. Camões e o sentimento nacional. Porto: Livraria Internacional de Ernesto Chardron.

CAMÕES, Luís de. 2000. Os Lusíadas. Lisboa: Ministério dos Negócios Estrangeiros / Instituto Camões.

Dias, Augusto da Costa. 1977. A crise da consciência pequeno-burguesa. O nacionalismo literário da Geração do 90. Lisboa: Estampa.

Eliade, Mircea. 1972. Mito e realidade. Trad. Pola Civelli. São Paulo: Perspectiva.

Garrett, Almeida. 2014. Frei Luís de Sousa. Porto: Porto Editora. 


\section{$84 \square$ LA CONSTRUCCIÓN MÍTICA DEL QUINTO IMPERIO PORTUGUÉS}

LOURENÇO, Eduardo, "Da literatura como interpretação de Portugal". O labirinto da saudade. Psicanálise mítica do destino português. Lisboa: Gradiva. Pp. 80117.

NoBRE, António, Despedidas. Web: 13 de octubre de 2016. <http://www.projeto livrolivre.com/Despedidas $\% 20-\% 20 \% 20$ Antonio $\% 20$ Nobre $\% 20 \% 20-\% 20$ Iba\%20Mendes.pdf $>$.

Pascoaes, Teixeira de. 1978. Arte de ser português. Lisboa: Roger Delraux.

PessoA, Fernando. 1993. Mensagem. Poemas esotéricos. Ed. José Augusto SeABRA. UNESCO. (Col. Archivos, 28) 1979. Sobre Portugal, Introdução ao Problema Nacional. Comp. Maria Isabel RochETA y Maria Paula MoRÃo. Lisboa: Ática. Web: 22 de octubre de 2016, <http://multipessoa.net/labirinto/portugal/14>, y 2 de noviembre de 2016, <http://arquivopessoa.net/textos/1180>.

QuAdros, António. 1982. Poesia e filosofia do mito sebastianista. Lisboa: Guimarães.

SARAIVA, José António. 1992. “António Vieira, Menasseh Ben Israel e o Quinto Império". História e utopia. Estudos sobre Vieira. Lisboa: Instituto de Língua e Cultura Portuguesa. Pp. 75-106.

y Óscar LóPES. 2000. História da Literatura Portuguesa. Porto: Porto Editora.

SOLER, Isabel. 2003. El nudo y la esfera. El navegante como artifice del mundo moderno. Barcelona: Acantilado. 